\title{
Does Financial Liberalization Stimulate Economic Growth and Reduce Poverty in Six Sub-Saharan African Countries?
}

\author{
Muhammad Yusuf ${ }^{1}$, Chinnasamy Agamudai Nambhi Malarvizhi' $\&$ Sreenivasan Jayashree $^{2}$ \\ ${ }^{1}$ Department of Economics, Umaru Musa Yaradua University, Katsina State, Nigeria. \\ ${ }^{2}$ Faculty of Management, Multimedia University, 63100 Selangor, Cyberjaya, Malaysia \\ Correspondence: Muhammad Yusuf, Department of Economics, Umaru Musa Yaradua University, Katsina State, \\ Nigeria. Tel: 234-80-3049-8522. E-mail: yusudume@yahoo.com
}

Received: September 27, 2013

Accepted: November 18, 2013 Online Published: January 20, 2014

doi:10.5539/ijbm.v9n2p166

URL: http://dx.doi.org/10.5539/ijbm.v9n2p166

\begin{abstract}
This paper examines the linkage between financial liberalization, economic growth and poverty reduction in Sub-Saharan African countries (SSA). The study applys the recent panel Co-integration and vector error correction mechanism to address the heterogeneity and cross-border interdependence over the period of 1980 to 2010. The results reveal that economic growth is positively associated with poverty reduction and financial liberalization coefficients are positively related to economic growth. This implies that financial liberalization causes economic growth. However, the coefficients of financial liberalization are not significant in the poverty equation, which suggests that financial liberalization does not have direct impact on poverty reduction in the six Sub-Saharan African countries. This implies that the financial liberalization effects of poverty are upon contingent on the distributional changes introduced by the growth and the configuration of institutions and policies accompanying the liberalization process and the existence of good governance.
\end{abstract}

Keywords: liberalization, poverty, economic growth, financial repression

\section{Introduction}

It is a well known the case that financial liberalization and its effects on economic growth and development has been an area of considerable attention. Despite these prolific developments, little has been done on the relationship between financial liberalization and reduction of poverty. The current bodies of literature have been, to a great extent dominated by the free market neoclassical ideas which support the argument that financial sector liberalization mobilizes savings and channels capital into the most appropriate product uses. By implication, both of which improves the amount of physical capital and its productive uses. This invariably means, financial liberalization raises the level of economic growth. By implication then, economic growth due to financial liberalization raises the level of income and such reduce the level of poverty. Thus, with regards to countries in Sub-Saharan Africa these ideas have been contested (Arestis \& Glickman, 2002). The recent development in most countries in Sub-Saharan Africa succinctly raises a fundamental question of concern on whether financial liberalization exacts on both economic growth and poverty reduction. Studies also question whether liberalization of the financial sector helps in the increase in the amount of physical capital and productivity and also leads to faster economic growth and poverty reduction.

The revealing revelation abount the SSA financial secotor performance has indicates that the financial sectors of the SSA countries are one of the poorly developed in the World. The average GDP per capita growth rate from 1961 to 2000 was 0.45 percent. There is no much progress recorded in the mobilization of domestic resources for productive investment, since the inception of the financial liberalization program. The region growth domestic saving as a proportion of GDP is below 20 percent. The financial global crisis accompanies financial liberalization has worsened the internal resources of the region. On the social indicators, poverty and inequality of economic continue to worsen indicating that economic growth has not been trickling down to the poor. The continent is experiencing a jobless recovery from the financial meltdown, with a deteriorating fiscal deficit and current account balance. The absolute number of people living in extreme poverty has been on the rise in SSA, the incidence of poverty fell marginally, from 54 to 51 percent between 1981 and 2005 (UNDP, 2010). SSA faces major challenges in meeting the 2015 Millennium Development Goal target. Furthermore, income inequality has grown in the region. 
These associated characteristics of the SSA financial secotor performance raised the points of contestation whether removal of all forms of restrictions on financial sector by allowing the market forces to allocate credit has created a better performance of investments- Some studies have pointed out that most countries in Sub-Saharan African are characterized by imperfect information, uncertainties, lack of perfect competitions, inadequate prudential supervision coupled with a minimum level of accountability, poor legal framework and price instability (Arestis and Glickman 2002). Therefore, this raised questions of whether liberalization of the financial sector based on the assumption of perfect market can improve the level of physical capital and its productivity. From the mechanism put in place, some raised the question: To what extent such a mechanism underlying the transition from financial repression to financial liberalization can benefit various aspects of the society, especially for the poor? Despite- the obviuos question, the traditional free-market neoclassical economists supported by the IMF and World Bank still maintained the view that the slow growth and the alarming rate of persistent poverty in Africa were attributed by financial repression. They insist that the restriction on the financial transaction such as the interest rate control or considerable reserve requirement were the main causes of the low growth and poor driven allocation of financial resources (Mckinnon, 1991).

On the general note, however, a more common view appears to be that whether financial liberalization lead higher growth and poverty reduction or not is contingent on both domestic and external factors. Fry (1995) argued that there is an urgent need for complementary effective prudential and supervision guideline with high level of accountability, price stability and fiscal discipline Fry (1995) argued that financial liberalization may not increase the growth performance of the SSA countries since these countries are to some extend associated with asymmetric information, lack of perfect competition, macroeconomic volatility as they are all manifest of market failures. In such an environment, financial regulation may be the only choice to lower the interest rate in which the average productivity by saving and investment can be stimulated. A lower interest rate could also, raise-productivity of physical capital through the low marginal cost of production and provide a venue of channeling pool saving into technological deficiencies sectors. The general agreement is that financial liberalization depends upon the institutional context of the economy of the SSA and, particularly the prevalence of good governance or otherwise. This also raised the issue of whether the increased growth due to liberalization is supported by equitable income distribution that allows poor people to share in growth (Arestis 2005).

The objectives of this paper are to empirically examine the preposition purports to show that six SSA countries (Nigeria, Ghana, Cote d'Ivoire, Cameroun, Gambia, Botswana liberalization of their financial sector has led to faster growth and reudtion in poverty. The empirical studies of (Fowowo, 2011, Honohan 2004, Len Sink 1996, Allen and Ndikumana, 2000 and Aziakpomo, 2004) have employed Panel GMM but the problems with their panel time series analysis they often assume slope homogeneity or cross-sectional independence, which may lead to incorrect causal inferences. This study aims to improve often on the previous studies in the SSA region by using Panel co-integration and Panel Causality which allowed sample heterogeneity and examine the crosscountry interdependence. This study Utilized both time-series and cross-sectional data from seven SSA countries over the period of 1980 to 2010 .

The remaining part of this study is structured as follows: The subsequent part of the paper reviews the theoretical and empirical literatures connecting financial liberalization to growth and poverty reduction. Section 3 presents methods and materials of the study, while section 4 , and presents the results and discussions. Finally section 5 ends the paper with a summary and conclusions.

\section{Materials Studied}

\subsection{Theoretical Literature}

The relationship between financial sector liberalization and economic development could be linked to contrasting perspectives of finance and growth theories, each promoting different ways of influence. These differences have led to a number of empirical researches testing the reliability of these approaches; hence different conclusions were derived from the studies.

There are two major schools of thought advancing the argument on financial liberalization which includes, the finance-based theory or interventionists and neoclassical free market advocates, each advocating different transmission mechanism of the linkage between the financial sector, economic growth and poverty reduction. According to the non-interventionists theories which was associated with the work of Mckinnon and Shaw (1973) which were built on the work of Schempeter (1911) provides two important ways in which financial repression affects economic growth. The first, they believed that financial repression affects the efficiency of saving allocation and the productive investment, in other words, financial repressions affect the rate of return on saving and even affect the equilibrium level of saving and investment. This happened because investment is 
affected by the decision of bankers who allocate investment funds according to their discretion, without considering the marginal productivity of investment. These tendencies from the banker's decision in turn, discourage the potential savers and persuade them to keep their savings in unproductive assets. Secondly, excessive increase in the level of reserve requirement decreases the supply of cash to the banks hence, affects their lending, and credit allocation.

To ameliorate these problems, this school of thought suggests systematic elimination of regulatory control measures and operational guidelines, such as removal of the credit control program, deregulation of interest rate ceilings and decreasing the reserve requirements, will in turn stimulate economic growth and efficient allocation of resources and finally, translate growth into a reduction in poverty. Mckinnon and Shaw (1973) emphasized that regulating the financial sector was the major cause of the declined in the real rate of growth and the real rate of the financial development in relation to the non financial sectors. Such as removing all forms of restriction on the interest rate and allow it to be determined by the free- market equilibrium level, will enhance the level of both savings and productive investment.

On the contrary, the interventionists/ financial regulation theorists lunched their criticism on the financial liberalization thesis based on the Keynesian model which emphasized on the role of effective demand. According to the interventionists' views, a shift in the deposit interest rate raises the marginal propensity to save and as such decreases aggregate demand. A fall in aggregate demand and output causes a fall in profit and fall in profit causes a fall in investment. This means that investment will be lower under financial liberalization than that in the financial repression (Stiglizt, 2000). The second criticism of the financial liberalization thesis emerged from the work of Stiglitz, (1999); Fry, (1995); Arestis and Demetriades (1999) who holds the believed that financial liberalization is prone to market failure because of high information costs which is associated with high transaction costs. This is also due to the facts that monitoring banks are part and parcel of public goods therefore, high information costs create negative externalities which have multiplier effects on the entire rest of the economy.

However, those views where an attack to the early growth theory of Slow (1952) who stresses the importance of capital accumulation and sufficient saving for achieving faster economic growth and more efficient allocation of resources through free market fundamentals.

\subsection{Empiral Literature}

On the empirical grounds, findings on the relationship between financial liberalization and growth, however, are mixed and inconclusive. The general agreement is that higher level of financial sector development is associated with high rates of economic growth, while some argue against. One of the interesting works in support of this hypothesis is the work of Bonfiglioli (2008) who use dynamic panel analysis based on the system GMM on the variables of liberalization, growth and poverty, drawing data from samples of selected countries out of 70 developing and developed countries. The results revealed that financial liberalization significantly impact on productivity growth. However, the problems with the study of Bonfiglioli (2008) are presumed slope homogeneity without taking into cognizance the heterogeneity in the sample size.

Gehringer et al. (2013) examines the causal linkage between financial sector reforms and economic growth, drawing data from 26 EU countries, between 1990-2007; using the techniques of difference GMM. Their findings revealed that financial integration has significant positive impact on economic growth among the EU countries. Another multinational study is associated with the work of Bonfigioli (2008b) who examine the impact of financial liberalization on growth performance. Taking samples of 28 manufacturing industries from 56 countries over the period of 1963-2003. The results of the study indicated that financial liberalization positively affects economic growth along with entry of firms, capital accumulation and raised the level of employment. Another study of Bonfiglioli et al (2011) examines the linkage between financial liberalization, factor productivity and capital accumulation, using data of 96 countries collected between 1998-2006 periods of time, using the estimation techniques of pooled OLS. Their studies revealed that financial liberalization has significantly affected economic growth.

Fowowo (2013) examine financial sector reforms and the productivity in private investment in SSA, using a developed index. The author applied the techniques of generalized method GMM in order to address the problem of endogeneity bias. The study confirmed that financial sector reforms have had positive effects on private investment in the selected Sub-Saharan Countries. But the problem with the author study is the application of GMM which assume slope homogeneity without capturing coefficients heterogeneity and crosssectional interdependence. 
On the contrary, the findings of other studies have provided disappointing results on the performance of financial liberalization on economic growth. Such as the study of Stiglizt (2000) whose findings revealed that financial liberalization does not actually address the problems of asymmetric information which affects the intimidation function of a liberalized market existing in the poor countries.

Enowbi Batu (2012) use different approaches to measure financial liberalization and banking crisis. The findings of the study suggested that even though liberalization may succeeds in reducing the cost of production but there is the possibilities that banks may end up financing more risky projects and over time project with lower return will be accepted which could make banks more vulnerable to crisis. Oshikoya (1992) apply time-series data to measure the effects of interest rate liberalization on economic growth in Kenya uses the data of 1970 to 1989 . The findings of the study indicate that liberalization of interest rate causes economic growth in Kenya.

Soyibo and Ade (1994) use the method of correlation graphs to measure the linkage between economic growth and financial intermediation, collected data from 11 countries in Africa, using the ratio of currency, demand deposits, and time and saving deposits to GDP. The results of their study did not show any evidence that financial liberalization causes economic growth.

The debate on the linkage between financial liberalization and poverty has little attention in the academic research. Some of the claims both at theoretical and empirical level have been mixed. One of the noteworthy studies is the work of (Jalilian and Kirkpatricks, 2002) who examines the nexus between financial liberalization and poverty via economic growth. These authors' study was motivated by the work of Dollar and Kraay whom study confirms the positive impact of economic growth on poverty. The authors estimate two equations, a growth and poverty regression in the growth regression; they pay more attention on the financial liberalization variables in the estimation. The authors also identified a number of control variables in the poverty regression. The finding of their study indicates that one unit change in financial liberalization is associated with a 0.4 percent change in the growth rate of the income of the poor.

Another study associated with the work of Ariste et al. (2004), provides way through which financial liberalization affects poverty. One of such ways is through financial crisis which follow after financial liberalization of which lead to fall in the earnings of both the formal and informal-sector workers due to job losses in the formal sector and fall in the demand for services in the informal sector.

Fowowo (2011) argue that the poor are denied access to institutional finance because financial liberalization fails to integrate the creative part of the poor in the institutional arrangement. But Honohan (2004) who examine the linkages between financial institutions and poverty reduction argued that financial development affect only one segment of the society whose shares of income is under one dollar a day. In a related study Beck et al (2008) apply cross-sectional analysis of 52 developing and developed countries over a period of 1960 to 1990 . They found that financial intermediary development has a significant impact on the poor. Thus, the critiques note, the problems with the study of Honohan (2004) and Beck et al (2008) is the omission of variable biases.

However, in order to address the methodological problems with the studies of (Honohan, 2004; Beck et al , 2008). Jeanneney and Kpodar (2011) integrated the variable of financial instability into financial development variables. The results of their study indicate that financial depth? Is significantly affecting poverty reduction. But they argued that the ratio of credit to GDP did not positively affect poverty reduction. They used econometric analysis as an evidence to support Mckinnon (1973) views that financial intermediaries do not directly affects poverty reduction but have a great influence on economic growth which in turn affect poverty reduction indirectly.

Whether financial liberalization leads to better access to credit for the disadvantage borrowers and savers, the study of Len Sink (1996) provides indebt explanation. The author argued that financial liberalization through the formal sector may cause decreases in savings and decreases in the amount of investment which results in the decline in the allocative efficiency of capital. The author argues that in SSA financial liberalization failed to realize that the formal banking sector are less important for financing investment project.

\section{Methods}

To examine the relationship between financial liberalization, growth performance and reduction in poverty this study used the data collected from six countries over the period 1996 to 2011. Growth of real GDP per- capita (real GDP per capita in constant price) was used to measure economic growth. We use poverty represented by the head counts index (defined as the percentage of the population under a dollar daily income) Data were extracted from the WDI (World Bank). Chin- Ito index were used to represent financial openness. These indexes 
allowed to investigate the extent of financial openness for a country in a given period of time, which was developed based on binary series based on the IMF report of exchange Arrangement and exchange restriction (AREAR). The rest of the indices (FR1andFR2) are developed from five component parts of the financial liberalization policies

The common problems with previous studies on panel time series analysis they often assume slope homogeneity or cross-sectional independence, which may lead to incorrect causal inferences. This study aims to improve often on the previous studies in the SSA region by using Panel co-integration and Panel Causality which provide sample heterogeneity and examine the cross- country interdependence. In this case co-integrating vectors are used through the fully modified (FM) OLS approach which take care of the heterogeneity of the coefficients and also allow consistency in the long run relationship with the short- run adjustment. The countries studied are Nigeria, Cameroun Ghana, Gambia, Botswana and Cote d'Ivoire.

\subsection{Panel Unit Root Tests}

Different approaches for the estimation of a unit root in a panel data has been established with the aim of integrating information from time series data with that of the cross-sectional information. These are classified under the four panel unit root test which is Levin, Lin and Chu (LLC) test, IM, Pesaran and Shin (IPS) test and PP- fisher test. The first generation test was developed by Levin and Lin (1993) which suffer a number of shortcomings. The problem with this first generation test is that they do not allow for heterogeneity in the autoregressive coefficient. This new generation test was specified as follows:

$$
\Delta \beta i, t=\varphi i+\beta t+\sum \varphi i j \Delta \beta i, t-j+\eta i, t
$$

Where $\Delta$ the first difference operation $\eta \mathrm{i}$ is the random terms and sigma for changes of $\varphi^{2}, t=1,2 \ldots \ldots t$ stand for time period, and $i=1,2 \ldots .10$ represents regional cross- time series

This approach made it easy to determine the two dimensional fixed effects ( $\delta$ and $\partial$ ) and unit exact period time trends. Levin, Lin and Chu test, includes the first and null hypothesis $H o: \beta i=0$ for all $\mathrm{i}$, which is tested on the opposite under the alternative hypothesis $\mathrm{Hi} \beta i=\beta \prec 0$ for all $\mathrm{i}$.

However, the framework, of analysis was extended by the Levin, Lin and Chu (2002) analysis in order to take care the presence of heterogeneity of the coefficient terms in the alternative hypothesis. While on the other hand, Pesaran and Shin (2003) have compromised the similarity of the first order AR coefficient of the Levin, Lin and Chu test that enable $\beta$ become not similar along the cross-sectional region in the alternative hypothesis. Both hypotheses are specified as $\mathrm{H} 0 ; \beta i=0 \quad \mathrm{i}, \mathrm{HI}=\beta i \quad 0$ in certain $\mathrm{i}$. While IPS measure is conducted on the basis of the mean group procedure IPS exhibit their approach as appropriate with the finite sample ability when compared with the Levin Lin and Chu approach. The Fisher-ADF test developed by Choi (2001) and the Fisher, PP test developed by Pedroni (1999) used probability by applying an asymptotic Chi-Square approach. One good merit of using the Fisher test, in place of IM Pesaran test, it doesn't need balance panel, it also enable the application of various lag lengths in the separate ADF estimate and can be easily estimated in the case of any derived Unit roots test. The major demerit of the Fisher test lies in the way the Probability- values were established based on Monte Carlo.

\subsection{Cross-Sectional Panel Co-Integration}

Pedroni (1999) developed various estimates using residuals found in the work of the Engle and Granger, (1987) Panel co -integration techniques allow the estimation of homogeneity. Because heterogeneous parameters, fixed effects and individual specific deterministic trend are all allowed Pedroni (2004). With this development Pedroni established Seven Panel co- integration statistics, four are known as the pool panel co- integration statistics, and they are categorized within dimension based statistics. While the rest of the three are called mean panel co- integration statistics and they all fall between-dimension based.

Pedroni (1999) pointed out that long time period cases with a number of observations above 100 have a minimum sample size distortion, thereby maintaining a large power of test within the seven statistics in all cases. On the contrary panel with short spans their alternative statistics yield conflicting results. Engle and Granger (1987) pointed out that the group of ADF reveals a better testing power, followed by Panel ADF. But on the other hand, the panel-variance and group $\mathrm{p}$ statistics function less effectively in relative to the others.

\subsection{Panel Vector Error Correction Model}

Whenever, a model is found to be co-integrated it indicates the possible existence of causality which is determined through the application of PVECM:

$$
\Delta \delta i t=C i+\sum \beta k \Delta \delta i, t-k+\lambda t e c i, t-1+U i, t
$$


Where $\delta$ is the vector of variables, comprising the GDP, POVT, KO, and FR1and FR2. While "I" stand for Panel characteristics of cross-country analysis, "ec" stands for the error terms $\lambda$ ui stand for the rate of adjustment to the long run equilibrium equally.

\section{Results and Discussions}

Before proceeding to integration and causality test it is imperative to provide the descriptive analysis of the data to ensure whether the data is normally distributed or otherwise. In a situation where the data appear with certain abnormalities the integration order to the data has to be ensure in all series. In doing so we estimated the descriptive statistics in table 1 below as well as the unit root test in both level and first difference and the results are presented in tables 2 and 3 below.

Table 1. Descriptive statistics

\begin{tabular}{lcccc}
\hline & LNGDP & LNPOVT & KO & FA \\
\hline Mean & 1601.280 & 16.33646 & -0.053063 & 1617.563 \\
Median & 973.9750 & 13.00000 & -1.168828 & 985.7061 \\
Maximum & 8532.617 & 32.90000 & 2.439009 & 8565.656 \\
Minimum & 259.9907 & 0.425000 & -1.863972 & 272.7219 \\
Std. Dev. & 1719.814 & 10.62194 & 1.549316 & 1724.730 \\
Skewness & 2.202836 & 0.128556 & 0.814065 & 2.207758 \\
Kurtosis & 7.356604 & 1.861378 & 1.851194 & 7.361976 \\
Jarque-Bera & 153.5597 & 5.450261 & 15.88225 & 154.0945 \\
Probability & 0.000000 & 0.065538 & 0.000356 & 0.000000 \\
Sum & 153722.9 & 1568.300 & -5.094045 & 155286.1 \\
Sum Sq. Dev. & $2.81 \mathrm{E}+08$ & 10718.43 & 228.0360 & $2.83 \mathrm{E}+08$ \\
Observations & 96 & 96 & 96 & 96 \\
\hline
\end{tabular}

Table 1 above indicate that skewness is not closed to zero on LNGDP and FA, while in the case of LNPOVT and KO skewness is achieved. Thus Kurtosis is not closed to three on LNPOVT and KO and it is greater than three in the LNGDP and FA. This indicate that the data is not normally distributed. However the probability also reveals that the data is not greater than 5 percent as such the data is not normally distributed. This call for the unit root test in order to ensure that the data is cointegrated before its application into estimation.

Table 2. Panel unit root results at level

\begin{tabular}{lcccc}
\hline & LL & IPS & ADF-Fisher & Pp-fisher \\
\hline FA & -1.27516 & -0.58884 & 12.7764 & 14.2748 \\
& $(0.1011)$ & $(0.2780)$ & $(0.3855)$ & $(0.2835)$ \\
LPOVT & -2.29915 & $2.35794 *$ & 17.7229 & 19.2979 \\
& $(0.0107)$ & $(0.0092)$ & $(0.0234)$ & $(0.0133)$ \\
LNGDP & -0.06881 & -0.31575 & 21.1638 & $37.8803^{*}$ \\
& $(0.4726)$ & $(0.3761)$ & $(0.0200)$ & $(0.0000)$ \\
KO & -1.46401 & -1.12256 & 19.0032 & 22.0047 \\
& $(0.0716)$ & $(0.1308)$ & $(0.0885)$ & $(0.0376)$ \\
\hline
\end{tabular}

Note: $* *$ and ${ }^{* * *}$ suggest the rejection level at the $10 \%, 5 \%$ and $1 \%$ level accordingly.

Table 2 presents the results of the panel unit root test with LLC, IPS, ADF, Fisher and PP- fisher test. The results of the null unit root test at level indicate that the series are not stationary at level with the exception of LPOVT which is significant at IPS and LNDGDP at PP fisher. In order to ensure the stationary of the data another unit root test is estimated at first differences which is presented in table 3 below. 
Table 3. Panel unit root results at first difference

\begin{tabular}{lllll}
\hline & LCC & IPS & ADF-Fisher & PP-Fisher \\
\hline FA & $-12.6132^{*}$ & $-11.1293^{*}$ & $113.416^{*}$ & $127.088^{*}$ \\
\multirow{2}{*}{ LPOVT } & $(0.0000)$ & $(0.0000)$ & $(0.0000)$ & $(0.0000)$ \\
& $-8.52930^{*}$ & $-8.21637^{*}$ & $59.0147^{*}$ & $59.0076^{*}$ \\
LNGDP & $(0.0000)$ & $(0.0000)$ & $(0.0000)$ & $(0.0000)$ \\
& $-7.62512^{*}$ & $-6.27426^{*}$ & $77.9587^{*}$ & $97.3907^{*}$ \\
KO & $(0.0000)$ & $(0.0000)$ & $(0.0000)$ & $(0.0000)$ \\
& $-12.6504^{*}$ & $-11.5028^{*}$ & $116.041^{*}$ & $143.2144^{*}$ \\
\hline
\end{tabular}

Note: $* *$ and $* * *$ suggest the rejection level at the $5 \%, 10 \%$ and $1 \%$ level accordingly.

Table 3 present the results of the panel unit root test with LLC, IPS,ADF, Fisher and PP- fisher test. The results indicates that all series become stationary after first difference, at $5 \%$ level of significance, therefore, the null hypothesis that there is unit root is rejected at first differences. With these the data is suitable for the econometrics estimation and anaylsis.

Table 4. Panel Co-integration test results (poverty as a dependent variable)

\begin{tabular}{lll}
\hline & Statistics & P-value \\
\hline Panel V & -1.204393 & 0.8867 \\
Panel P & 1.124252 & 0.8867 \\
Panel PP & $1.019771^{*}$ & 0.0067 \\
Group ADF & 1.663833 & 0.9519 \\
Group P & -0.869024 & 0.1924 \\
Group PP & $-4.85135^{*}$ & 0.0000 \\
Group ADF & $-11.7663^{*}$ & 0.0000 \\
\hline
\end{tabular}

Note: *** and $* * *$ suggest the rejection level at the $5 \%, 10 \%$ and $1 \%$ level accordingly.

To examine whether the variables under investigation

Table 4 is estimated to determine whether there is co- integration relationship among LNGDP KO, FA and LPOVT in SSA, through the newly established approach to panel co-integration developed by Pedroni (2004). The approach involves four panel statistics and three group panel statistics.

The results indicate that the null hypothesis of no co integration is rejected at $5 \%$ level of significance on panel PP, Group PP and Group ADF test statistics. This indicates that the variables move together towards stable equilibrium stage. It also implies that there is long run relationship among financial sector liberalization economic growth and poverty reduction in SSA. However, having long run relationship does not mean causality, as such to determine the direction of the causality, we estimate and analyse causality in the table 4

Table 5. Panel vector error correction mechanism results

\begin{tabular}{lllll}
\hline Independent Var. & $\Delta$ LPOVT $_{\mathrm{t}}$ & $\Delta \mathrm{LNGDP}_{\mathrm{t}}$ & $\Delta \mathrm{KO}$ & $\Delta \mathrm{FA}_{\mathrm{t}}$ \\
\hline $\mathrm{EC}_{\mathrm{t}-1}$ & $1.483692^{*}$ & $0.122430^{*}$ & 0.0206598 & $0.059365^{*}$ \\
& $(-2.62323)$ & $(-3.46582)$ & $(-2.95300)$ & $(-1.99367)$ \\
$\Delta \mathrm{LPOVT}_{\mathrm{t}-1}$ & 0.147188 & -7027661 & 0.001401 & 0.001025 \\
& $(0.64967)$ & $(-0.26426)$ & $(0.12120)$ & $(0.50103)$ \\
$\Delta \mathrm{LNGDP}_{\mathrm{t}-1}$ & $1.009466^{*}$ & -0.059555 & -8951112 & 2.599912 \\
& $(2.21335)$ & $(-0.75445)$ & $(-0.26087)$ & $(0.43168)$ \\
$\Delta \mathrm{KO}_{\mathrm{t}-1}$ & -0.257390 & $1.170008^{*}$ & -0.229702 & ------- \\
& $(0.07723)$ & $(2.45892)$ & $(-2.81355)$ & -0.087920 \\
$\Delta \mathrm{FA}_{\mathrm{t}-1}$ & 0.844202 & $6.766608 *$ & -------- & $(-1.10743)$ \\
& $(0.26263)$ & $(2.65196)$ & & -9.233305 \\
$\mathrm{C}$ & 0.273772 & -1.8670902 & -7.566605 & $(-0.01166)$ \\
\hline
\end{tabular}

Note: $* * * * *$ and $*$ indicate the significance at the $5 \%, 10 \%$, and $1 \%$ accordingly. The P-Value is given in parentheses. 
The results in table 5 above indicate that the error correction term is statistically significant with a positive coefficient on poverty model, suggesting that past disequilibrium changes in the poverty will be adjusted back to the steady and stable equilibrium in the current period. Hoever, in the poverty model with $\triangle \mathrm{LPOVT}_{\mathrm{t}}$ as the dependent variable the econometric result of the investigated coefficient of $\Delta \operatorname{LNGDP}_{\mathrm{t}-1}$ indicates a statistically significant positive value. This suggests that economic growth contributes to poverty reduction. Additionally, the coefficients of $\Delta \mathrm{KO}_{\mathrm{t}-1}$ and $\Delta \mathrm{FA}_{\mathrm{t}-1}$ which are the proxies of financial liberalization are significantly positive implying that financial liberalization has impacts on economic growth

However, the coefficients of $\Delta \mathrm{KO}_{\mathrm{t}-1}$ and $\Delta \mathrm{FA}_{\mathrm{t}-1}$ which are the proxies of financial liberalization are not significant, suggesting that financial liberalization does not have direct impact on poverty reduction. Thus, the six Sub-Saharan African country's financial liberalization does not have a direct impact on poverty reduction. The policy implication is that financial liberalization need to be supported with intervention policies that focus on the poor. Other wise certain group of few individuals continues enjoying the benefiti of financial liberalization at the expense of the poor.

\section{Conclusion}

In recent years many countries in SSA have witnessed tremendous reforms of their financial sector. While studies on the financial sector reforms and its benefit on economic growth and poverty reduction has received a great deal of attention (Mckinnon \& Shaw, 1973). This study investigates the causal linkage among the liberalization policy of the financial sector, economic growth and poverty reduction implemented within six SSA, This study contributes by utilizing financial liberalization indices that adequately capture the gradual nature and intensity of the financial market reforms. The study employed the techniques of panel Co integration and panel vector error correction mechanism in addressing the common mistake found in the previous studies of assuming slope homogeneity and cross-sectional interdependence.

The econometric results reveal that even though financial liberalization impact on economic growth, but the assumption that financial liberalization would at the end impact the poor through trickle down effects is not always the case. In the case of SSA the findings have shown that financial liberalization without first, sustaining macroeconomic stability, regulatory and supervisory frameworks, sound institutions and policies the financial sector liberalization may end up worsening the living standard of the poor. The implication is that financial liberalization in the case of SSA needs to be fashion out with poverty reduction thrust in order for the program to benefit the poor segment of the society.

\section{References}

Arestis, P., \& Demetriades, P. (1999). Financial liberalization: the experience of developing countries. Eastern Economic Journal, 25(4), 441-457.

Arestis, P., \& Stein, H. (2005). An institutional perspective to finance and development as an alternative to financial liberalisation. International Review of Applied Economics, 19(4), 381-398. http://dx.doi.org/10.1080/02692170500208459

Beck, T., \& Levine, R. (2008). Legal institutions and financial development. Retrieved from http://www.nber.org/papers/w10417

Bencivenga, V. R., \& Smith, B. D. (1991). Financial intermediation and endogenous growth. The Review of Economic Studies, 58(2), 195-209. http://dx.doi.org/10.2307/2297964

Bonfiglioli, A. (2008). Financial integration, productivity and capital accumulation. Journal of International Economics, 76(2), 337-355. http://dx.doi.org/10.1016/j.jinteco.2008.08.001

Chinn, M., \& Ito, H. (2011). Financial Globalization and China.

Choi, I. (2006). Combination unit root tests for cross-sectionally correlated panels. Econometric Theory and Practice: Frontiers of Analysis and Applied Research: Essays in Honor of Peter CB Phillips. Cambridge University Press.

Enowbi Batuo, M., \& Mlambo, K. (2012). Financial liberalisation, Banking Crises and Economic Growth in African Countries. http://mpra.ub.uni-muenchen.de/id/eprint/41524

Fowowe, B. (2008). Financial Liberalization Policies and Economic Growth: Panel Data Evidence from Sub-Saharan Africa. African Development Review, 20(3), 549-574. http://dx.doi.org/10.1111/j.1467-8268.2008.00198.x

Fowowe, B. (2013). Do Fiscal Incentives Promote Investment?: Empirical Evidence from Nigeria. The Journal 
of Developing Areas, 47(2), 17-35. http://dx.doi.org/10.1353/jda.2013.0029

Fry, M. J. (1997). In favour of financial liberalisation. The Economic Journal, 107(442), 754-770. http://dx.doi.org/10.1111/j.1468-0297.1997.tb00041.x

Green, H. J. (1960). Growth models, capital and stability. The Economic Journal, 57-73. http://dx.doi.org/10.2307/2227482

Honohan, P. (2004). Financial development, growth, and poverty: how close are the links? Retrieved from http://www-wds.worldbank.org/servlet/WDSContentServer/WDSP/IB/2004/03/30/000160016_200403301 43253/Rendered/PDF/wps3203.pdf

Im, K. S., Pesaran, M. H., \& Shin, Y. (2003). Testing for unit roots in heterogeneous panels. Journal of Econometrics, 115(1), 53-74. http://dx.doi.org/10.1016/S0304-4076(03)00092-7

Iyengar, B., Gehringer, E., Wolf, M., \& Manivannan, K. (2013). Scalable concurrent and parallel mark. $A C M$ SIGPLAN Notices, 47(11), 61-72. http://dx.doi.org/10.1145/2426642.2259006

Jeanneney, S. G., \& Kpodar, K. (2011). Financial development and poverty reduction: Can there be a benefit without a cost? The Journal of Development Studies, 47(1), 143-163. http://dx.doi.org/10.1080/00220388.2010.506918

King, R. G., \& Levine, R. (1993). Finance and growth: Schumpeter might be right. The quarterly journal of economics, 108(3), 717-737. http://dx.doi.org/10.2307/2118406

Levin, A., Lin, C. F., \& James Chu, C. S. (2002). Unit root tests in panel data: asymptotic and finite-sample properties. Journal of Econometrics, 108(1), 1-24. http://dx.doi.org/10.1016/S0304-4076(01)00098-7

McKinnon, R. I. (1989). Financial liberalization and economic development: a reassessment of interest-rate policies in Asia and Latin America. Oxford Review of Economic Policy, 5(4), 29-54. http://dx.doi.org/10.1093/oxrep/5.4.29

McKinnon, R. I. (1991). Financial control in the transition from classical socialism to a market economy. The Journal of Economic Perspectives, 5(4), 107-122. http://dx.doi.org/10.1257/jep.5.4.107

Oshikoya, T. W. (1992). Interest rate liberalization, savings, investment and growth: the case of kenya/liberalisation des taux d'interet, epargne, investissement et croissance: le cas du kenya. Savings and Development, 305-320.

Pedroni, P. (2004). Panel cointegration: asymptotic and finite sample properties of pooled time series tests with an application to the PPP hypothesis. Econometric Theory, 597-625.

Soyibo, A. (1994). Characteristics of the savings-investment process in Nigeria. World Development, 22(8), 1199-1210. http://dx.doi.org/10.1016/0305-750X(94)90086-8

Stiglitz, J. (1999). Whither reform. Washington, DC: The World Bank.

Stiglitz, J. E. (2000). Capital market liberalization, economic growth, and instability. World Development, 28(6), 1075-1086. http://dx.doi.org/10.1016/S0305-750X(00)00006-1

\section{Copyrights}

Copyright for this article is retained by the author(s), with first publication rights granted to the journal.

This is an open-access article distributed under the terms and conditions of the Creative Commons Attribution license (http://creativecommons.org/licenses/by/3.0/). 